\title{
Industrial implementation of a biosorption system with GAC
}

\author{
D. Kliaugaitè, I. Valūnas, I. Urniežaitė \& V. Račys \\ Department of Environmental Engineering, \\ Kaunas University of Technology, Lithuania
}

\begin{abstract}
This article represents the application of the biosorption process to the treatment of wastewater contaminated with light oil products. SC "Klaipedos nafta", which works in the field of transshipment of oil and its products in Lithuania, has installed biosorbers for the treatment of ballast and bilge water from the vessels. The biosorption process is sustained by integrated running of the Granulated Activated Carbon (GAC) and the active branches of particular microorganisms. This wastewater treatment method is preeminent for treatment of this kind of wastewater, compared with the treatment efficiency of other methods. Wastewater is pumped into biosorbers after flotation and the remaining concentration of Total Petroleum Hydrocarbons (TPH) varies by about $2 \mathrm{mg} / \mathrm{l}$. At the very beginning of the biosorbers operation wastewater treatment efficiency of $0.45 \mathrm{mg} / 1$ was reached. For the biosorption process control the main parameters are being analyzed: TPH, Suspended solids, COD, BOD, Total Nitrogen and Phosphorus, Detergents and Chloride. Interdependence of the values of these parameters and treatment efficiency is being established. The results obtained support the theory of the biosorption process and the process workability for the treatment of wastewater polluted with light oil products.

Keywords: biosorption, activated carbon, light oil products, ballast and bilge wastewater treatment, wastewater treatment efficiency.
\end{abstract}

\section{Introduction}

During oil extraction, transportation and use, natural waters are often polluted with oil hydrocarbons. When these compounds get into the environment, ecosystems are destabilized; part of the flora and fauna is lost. In the human organism, oil hydrocarbons can cause different diseases, including cancer. 
Because of their environmental risk, these compounds must be eliminated from wastewater (Cipinyte, [1]). In the laws of national environmental protection organization, permissible norms of oil hydrocarbons in the water are stated. In Lithuania their concentrations in water should not exceed $1 \mathrm{mg} / 1$ total petroleum hydrocarbons [2]. There are a number of water treatment processes which can be used singly or in combination to remove oil from wastewater [3]. For the pretreatment gravity separation, coalescence and flotation are usually used. The experience of companies working with oil products shows, that if oil products are strongly emulated or wastewater is contaminated with light oil products petroleum, aviation fuel or diesel - it is not enough to use mechanical treatment, if we want to clean water to the right norms; wastewater has to be treated additionally [4]. In such a case, a technological scheme is often supplemented by advanced biological, physical or biochemical treatment methods.

Activated carbon adsorption and biological degradation are two important processes used in the tertiary treatment of industrial wastewater contaminated with oil products (Poepel, [5]). These methods successfully supplement each other. For example, activated carbon adsorption can possibly allow the removal of toxic contaminants from the wastewater and thus ensures stable biological post-treatment. Inversely, biologically treated wastewater can be finally cleared with the help of a carbon filter (Sirotkin et al. [6]). Therefore, biochemical processes can be combined with sorption into one biosorption system, where biological treatment and adsorption take place simultaneously. Many authors (Sirotkin et al. [6]; Walker and Weatherley [8]; Dalmacija et al. [9]; Tumbas et al. [11]; Mochidzuki and Takeuchi [12]) state the fact, that biosorption is more efficient and cost-effective than the consecutive adsorption and biological treatment. These systems are capable of maintaining high levels of treatment and high degrees of stability and reliability.

This article presents the biosorption system installed in SC "Klaipedos nafta". The main parameters of its efficiency and control are given. The main objective of this article is to evaluate the suitability of industrial biosorbers for deep treatment of wastewater, contaminated with oil products.

\section{Research methodology}

Research was made in biosorbers, which were installed and started operatation in July 2005, in SC "Klaipedos nafta". The principle scheme of the process is given in Figure 1.

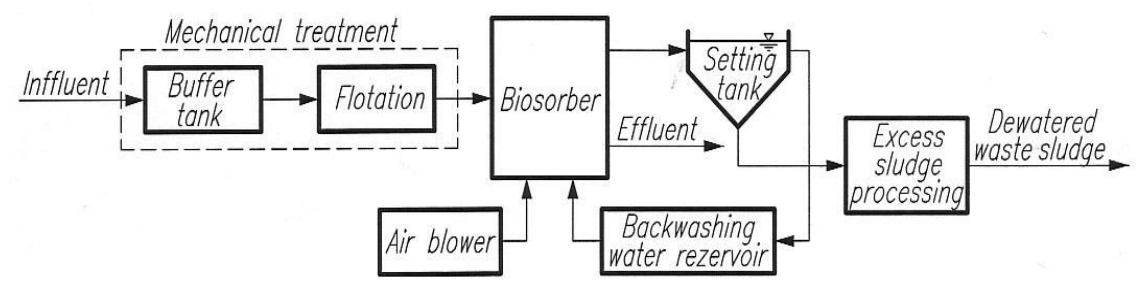

Figure 1: $\quad$ Principle scheme of biosorption process. 
Biosorbers in SC "Klaipedos nafta" work in SBR mode, they are filled, aerated and emptied in turn. The principle scheme (see Figure 1) shows that untreated wastewater with an average concentration of oil products of $3 \mathrm{mg} / \mathrm{l}$ goes to the flotator, where it is pretreated mechanically to a $2 \mathrm{mg} / \mathrm{l}$ concentration of oil products. Wastewater after mechanical pretreatment is fed to the biosorbers, for the biosorption process, which takes about 8 hours. Cleaned water goes directly into the Curonian Lagoon.

When hydraulic losses become too high, then backwashing is done. Backwashing water is fed from the reservoir through the drainage system. Water and excess sludge, collected during backwashing, goes to the settling tank. Thickened sludge is sent for further processing and water goes to the backwashing water reservoir and is used during the next backwashing.

The biosorber is filled with GAC and activated sludge. Microorganisms, which biodegrade oil products, are developing in the active sludge. Process aeration is maintained by air blowers, air is passed through the air diffusers, installed in the under part of the biosorber. The drain manifold with laterals is at the bottom of the biosorber.

The stages of the treatment process in the biosorber (SBR mode) are shown in Figure 2. Firstly the biosorber is filled with wastewater from the flotator. The process takes eight hours. Following the aeration stage takes place for about seven hours, after half hour sedimentation and half hour already treated water discharge.

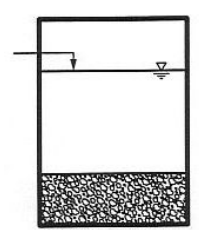

Filling

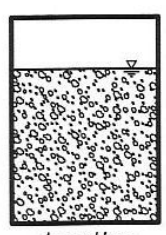

Aeration

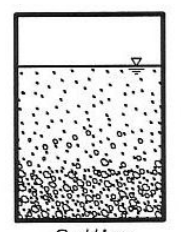

Setting

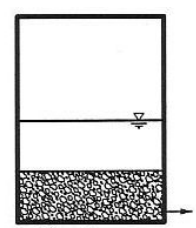

Discharge

Figure 2: $\quad$ Stages of the treatment process in the biosorber (SBR mode).

Wastewater in SC "Klaipedos nafta" is specific because of high salt concentration (in ballast water salinity ranges from 120 to $1000 \mathrm{mg} / \mathrm{l}$ ). Concentration of oil products in this kind of wastewater also has high fluctuations. On purpose, to speed up adaptability to wastewater contaminated with oil products, sludge was taken from the aerotanks of JSC "Mazeikiu nafta". Total initial sludge concentration in the biosorbers was about $0.15 \mathrm{~g} / \mathrm{l}$.

Systems efficiency is characterized by Biochemical Oxygen Demand (BOD), Chemical Oxygen Demand (COD), Total Petroleum Hydrocarbons (TPH), detergents, chlorides, nitrogen, phosphorus and suspended solids concentrations. Almost daily in a three month period the parameters TPH and suspended solids were determined. Other parameters such as BOD, COD, Chlorides, Total Nitrogen, and Phosphorus and Detergents were measured less frequently - two or one times in a week.

All parameters are determined by officially certified methodology. In parallel microscope analyses was done (microscope LEICA BME) of the active sludge and the vitality of the protozoa community studied. 


\section{Results and discussion}

The sampling was performed at SC "Klaipedos nafta" during the stage of wastewater treatment plant start-up works. Nevertheless, results of efficiency parameter analysis indicate significant ecological benefit of the plant. The main efficiency parameter of the biosorption systems is concentration of TPH, as we are dealing with the treatment of this type of wastewater. Thus far all ballast water at SC "Klaipedos nafta" was treated using flotation systems only and the concentration of TPH in effluent was about $2 \mathrm{mg} / \mathrm{l}$ (see Figure 3). The effluent from the biosorber contains the concentration of TPH over 4 times less - average concentration $0.45 \mathrm{mg} / \mathrm{l}$ (see Figure 3).

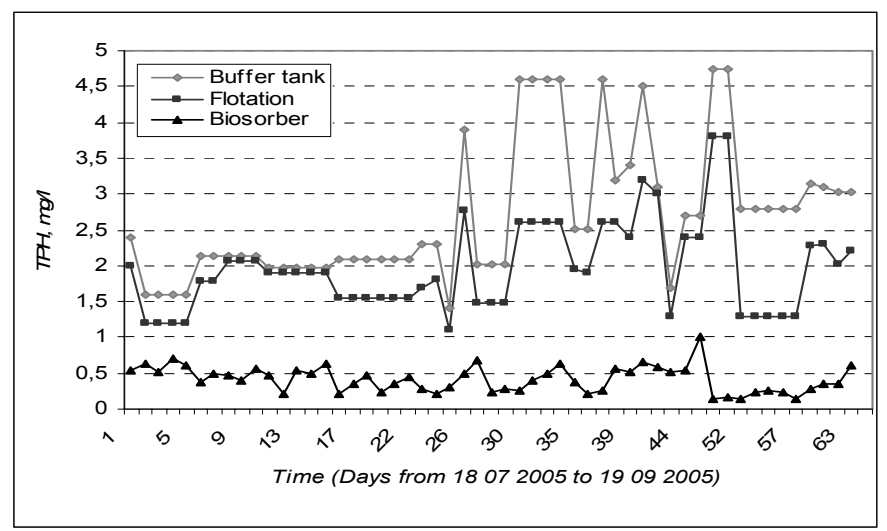

Figure 3: TPH changes in the buffer tank, flotator and biosorber (average concentration to flotator $-3 \mathrm{mg} / \mathrm{l}$, from flotator to biosorber - 2 $\mathrm{mg} / \mathrm{l}$, average concentration from biosorber $-0.45 \mathrm{mg} / \mathrm{l})$.

As can be seen from figure 3, the water coming from the buffer tank and flotator has high fluctuations with peak values of the TPH concentration, when effluent from the biosorber has small changes of TPH concentration; therefore this shows system stability. The data indicates that nearly $70-90 \%$ of the TPH may have been removed by the biosorption system.

The key feature of the biosorption system stable treatment performance during peak loads is the adsorptional capacity reserve created by the activated carbon bioregeneration (Sirotkin et al. [6]).

Figure 4 demonstrates incoming and outgoing concentrations of TPH every month. With gradually increasing TPH load in the range 1.7-2.2 mg/l (from July to September), the rate of TPH removal and efficiency increased. The efficiency of TPH removal was in the range of $71 \%$ (in July) and $88 \%$ (in September). Usually when only the sorption process takes place in the treatment the efficiency of contaminant removal during the time decreases. It is also important to take notice of the rather wide limits variation of the TPH load and the very small variation in outgoing water during September. In this way we can say that the surface of activated carbon was regenerated by microorganisms. 


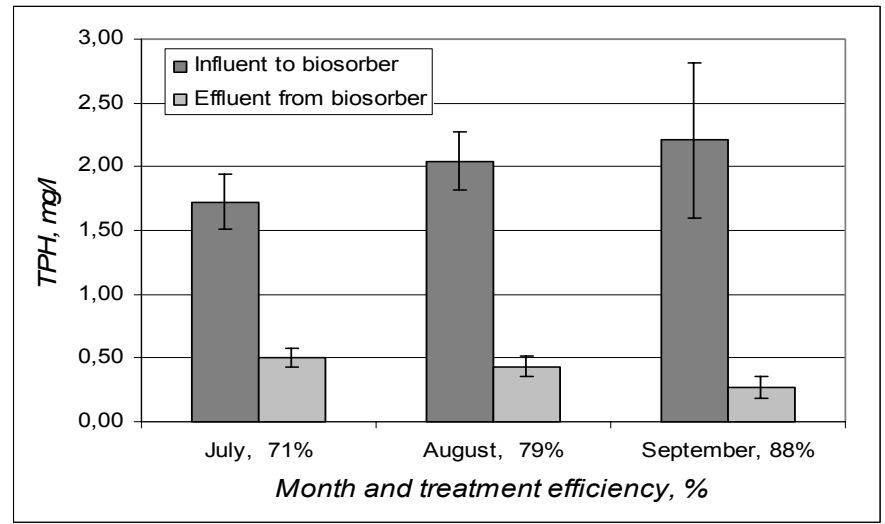

Figure 4: Average monthly values for TPH incoming and outgoing concentration and TPH removal efficiency, $\%$.

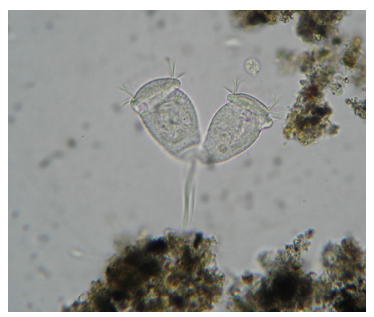

a

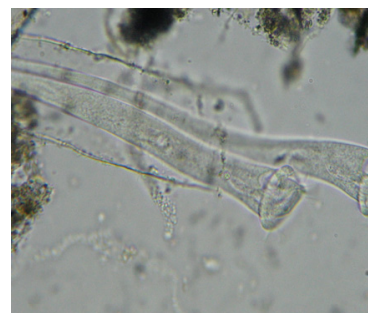

b

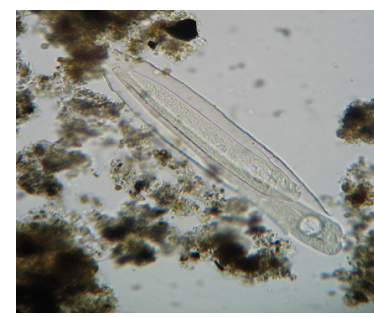

c

Figure 5: Microorganisms found in the active sludge: $a-$ Vorticella sp. b, cThuricola Fulliculata.

The microscopy analyses of the active sludge samples identified microbial cultures common for wastewater active sludge as Vorticella, Arcella, Euglypha ir Centopyxis Opercularia, Vorticella and specific for oil polluted wastewaters as Thuricola Fulliculata (see Figure 5). The microorganisms found are indicators of bacteria which are capable of biodegrading oil hydrocarbons (Mochidzuki and Takeuchi [12]).

All the facts prove the bioregeneration process occurs and it can be stated that the biosorption system is effective, stable and able to remove oil hydrocarbons below permissible limits.

Activated carbon in the biosorption system has the function of a sorbent and serves as the granular medium for the filtration. Thus the concentration of suspended solids in effluent from biosorbers is about $1.3 \mathrm{mg} / \mathrm{l}$, when the inlet water contains a concentration of about $12.6 \mathrm{mg} / \mathrm{l}$ (see Figure 6).

$\mathrm{COD}$ and BOD analysis results are presented in figures 7 and 8 respectively. It has to be stressed that in raw wastewater the loads of these parameters vary in a rather wide interval because as the ballast from tanker waters each day has a different degree of pollution. But an effective and steady working biosorption system ensures a high degree of organic removal: for $\mathrm{COD}$ in the range of $86.7 \%$, for the BOD in the range of $94.8 \%$ efficiency. 


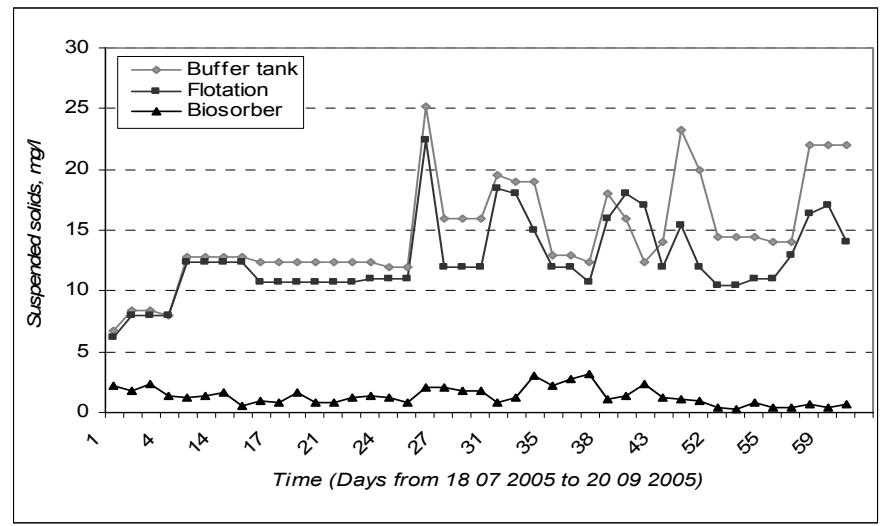

Figure 6: Suspended solid changes in the buffer tank, flotator and biosorber (average concentration to flotator $-14.7 \mathrm{mg} / \mathrm{l}$, from flotator to biosorber $-12.6 \mathrm{mg} / \mathrm{l}$, average concentration from biosorber -1.3 $\mathrm{mg} / \mathrm{l})$.

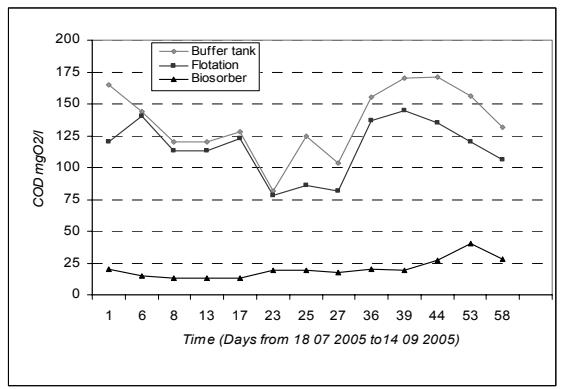

Figure 7: COD changes in the buffer tank, flotator and biosorber (average concentration to flotator - $123.4 \mathrm{mg} / \mathrm{l}$, from flotator to biosorber $106.8 \mathrm{mg} / \mathrm{l}$, average concentration from biosorber - $16.4 \mathrm{mg} / \mathrm{l})$.

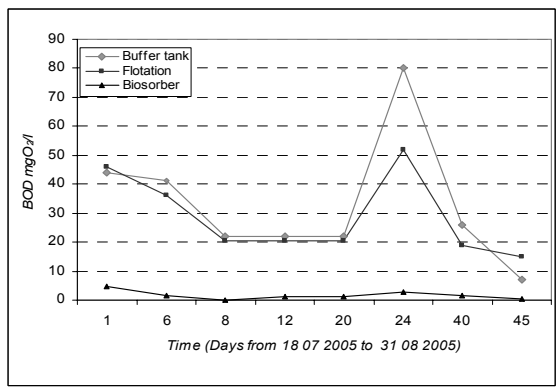

Figure 8: BOD changes in the buffer tank, flotator and biosorber (average concentration to flotator - $33 \mathrm{mg} / \mathrm{l}$, from flotator to biosorber - 28.7 $\mathrm{mg} / \mathrm{l}$, average concentration from biosorber $-1.7 \mathrm{mg} / \mathrm{l}$ ).

One more aspect is very important for analyzing BOD and COD parameters, the ratio $\mathrm{COD} / \mathrm{BOD}$ enables one to evaluate the possibility for biological treatment of wastewater. It is estimated that biological treatment of wastewater can be effective if the ratio COD/BOD is approximately 1.5 (Mochidzuki and Takeuchi [12]). The calculated ratio of the biosorber wastewater concentration is approximately 3.72 . A high degree of organic removal proves the workability of the biosorption system for removal of stable and organic compounds toxic to biological life. 


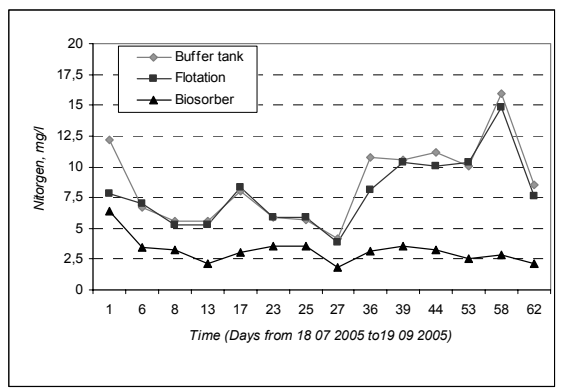

Figure 9: Nitrogen concentration changes in the buffer tank, flotator and biosorber (average concentration to flotator - $6.7 \mathrm{mg} / \mathrm{l}$, from flotator to biosorber -6.2 $\mathrm{mg} / \mathrm{l}$, average concentration from biosorber $-3.4 \mathrm{mg} / \mathrm{l})$.

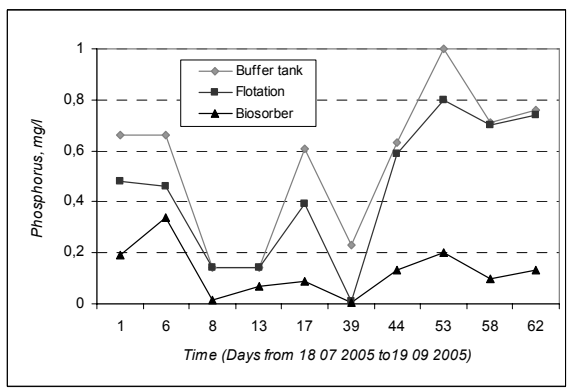

Figure 10: Phosphorus concentration changes in the buffer tank, flotator and biosorber (average concentration to flotator - $0.4 \mathrm{mg} / 1$, from flotator to biosorber -0.3 $\mathrm{mg} / \mathrm{l}$, average concentration from biosorber $-0.1 \mathrm{mg} / \mathrm{l})$.

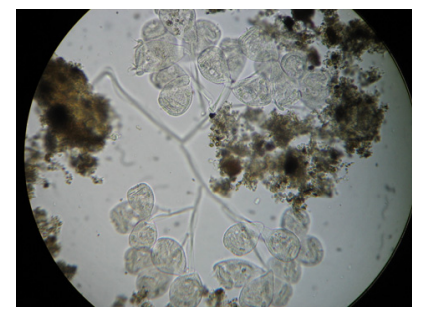

Figure 11: Opercularia $s p$.

Total nitrogen and phosphorus analyses results show a concentration decrease in the range of $6.2 \mathrm{mg} / 1$ to $3.5 \mathrm{mg} / \mathrm{l}$ and $0.3 \mathrm{mg} / \mathrm{l}$ to $0.1 \mathrm{mg} / \mathrm{l}$ respectively (see Figures 9 and 10). During the microscopy analysis Opercularia sp. Protozoa were found in the active sludge (see Figure 11). This is proof of the presence of the nitrification process as these protozoa are indicators of nitrifying bacteria [7].

Small concentrations of detergents (surfactants) were determined in the wastewater as well (see Figure 12). After treatment in the biosorber the concentration of detergents was reduced 3 times. Differently from TPH, suspended solids, BOD and COD, nitrogen, phosphorus and detergent removal is affected by fluctuations of initial concentrations.

Raw wastewater in SC "Klaipedos nafta" is specific because of the salts concentration (in ballast water salinity ranges from $120 \mathrm{mg} / \mathrm{l}$ to $1000 \mathrm{mg} / \mathrm{l}$ and sometimes more). Chloride concentrations were established in order to find the 
influence on chlorides on other contaminant removal efficiencies. Principal component analysis (PLS) was performed to find the relationship between the incoming chloride concentrations and the other compound removal efficiencies. During the sampling period, the chloride concentration varied from 90 to 500 $\mathrm{mg} / \mathrm{l}$.

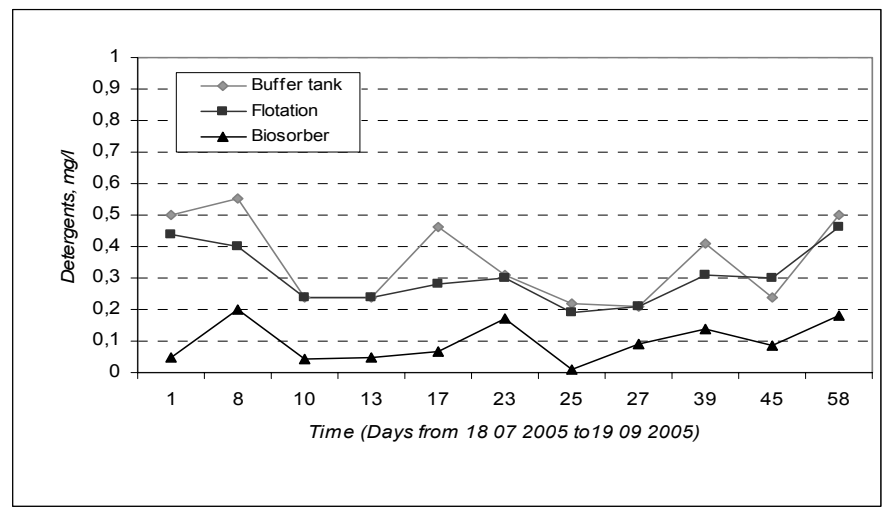

Figure 12: Detergent concentration changes in the buffer tank, flotator and biosorber (average concentration to flotator $0,34 \mathrm{mg} / \mathrm{l}$, from flotator to biosorber $-0.29 \mathrm{mg} / \mathrm{l}$, average concentration from biosorber $0.09 \mathrm{mg} / \mathrm{l})$.

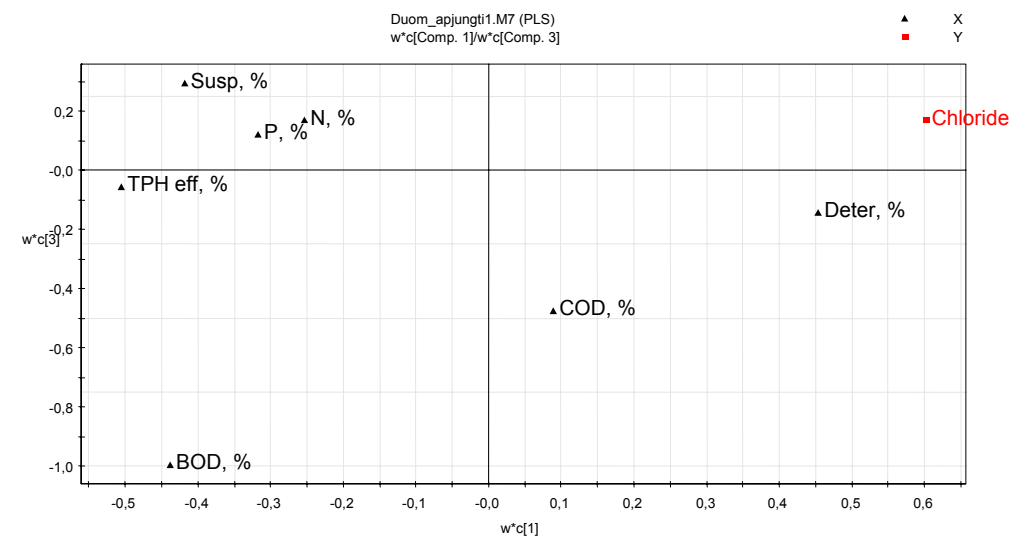

Figure 13: Principal component analysis (PLS) plot for finding the relation between incoming chloride concentration and other compound removal efficiencies.

Figure 13 illustrates that the most negative effect of chloride concentration is on TPH and BOD removal. Following parameters are located on the opposite 
side of the plot from the chlorides and are far from the coordinate axis. Treatment efficiency of COD wasn't sensitive to chlorides existence, however the detergents removal process was affected by chlorides in a positive manner.

\section{Conclusion}

It could be concluded that in raw wastewater the value of the measured parameters varies in a rather wide interval because the ballast waters from tankers each day have different degrees of pollutants, but still these fluctuations don't have a negative influence on the biosorption treatment process. All the measured parameters indicate that the removal of contaminants is stable and values of pollutants are below permissible limits.

Rather high and stable treatment efficiencies were established for TPH, suspended solids, BOD and COD. The results indicate that nearly $70-90 \%$ of the $\mathrm{TPH}$ may have been removed by the biosorption system. It is recommended to apply the biological treatment for wastewater when the ratio COD/BOD is approximately 1.5 , but this system works effectively even if the ratio COD/BOD in influent water is above 3.7 .

The microscopic analyses of the active sludge samples identified microbial cultures common for wastewater active sludge and cultures specific for oil polluted wastewaters. All identified microorganisms show the presence of bacteria, which are capable of biodegrading oil hydrocarbons.

The concentration of total nitrogen was reduced two times because the Mean Cell Residence Time is high and favorable conditions for denitrification are present in deep layers of GAC and biomass complex and in all biosorber volume when aeration is stopped for draining and filling up the biosorbers. It is important to mention that, differently from TPH, suspended solids, BOD and COD, such parameters as nitrogen, phosphorus and detergent removal are affected by fluctuations of initial concentrations. The higher load of compounds determines a decrease of treatment efficiency.

Principal component analysis shows that chlorides have a significant negative effect on TPH and BOD removal, but a positive effect on the treatment efficiency of detergents.

\section{Acknowledgement}

We are grateful to SC "Klaipedos nafta" for the possibility of using the laboratory facilities in a further investigation of the biosorption process in a real application.

\section{References}

[1] Cipinytè, V. Biological treatment of environment polluted with oil hydrocarbons. Summary of doctoral thesis. Vilnius, 2000.

[2] Lithuanian normative document for environmental protection (LAND 1096). Commandment of Ministry of Environment of the Republic of Lithuania Nr. 127. Vilnius, 1997. 
[3] Concawe. Trends in oil discharged with aqueous effluents from oil refineries in Europe: 2000 survey. Report no. 4/04, pp 10. 2004 (available at www.concawe.org).

[4] SC "Klaipèdos nafta" Additional wastewater treatment. Project. Vilnius, 2001.

[5] Poepel, H.J., Schmidt-Bregas, M. und Wagner M. Using of activated carbon for the wastewater treatment. Part 1. Korrespondenz Abwasser 35, pp.247-255, 1998.

[6] Sirotkin, AS., Koshkina, LY., Ippolitov KG. The BAC-process for treatment of waste water containing non-ionogenic synthetic surfactants. Water Research, Vol. 35 (13), pp 3265-3271, 2001.

[7] Environmental Leverage Inc. Web Site, 200509 14, USA, (available at http://www.environmentalleverage.com).

[8] Walker, G.M., Weatherley, L.R. Biological activated carbon treatment of industrial wastewater in stirred tank reactors. Chemical Engineering Journal, Vol. 75, No. 3, pp 201-206, 1999.

[9] Dalmacija, B., Tamas, Z., Miskovic, D. The biosorption of selected pesticides from water by biologically activated carbon. Water Science and Technology, 26 (9-11), pp 1991-1994, 1992.

[10] Maier, M., Maier, D., Lloyd, B. J. Conference on biofilm systems, program and proceedings October $17-20$. New York, pp 633-643, 1999.

[11] Tumbas, I.I, Dalmacija, B., Tamas, Z., Karlovic, E. Reuse of biologically regenerated activated carbon for phenol removal. Water Research, Vol. 32 (4), pp 1085-1094, 1998.

[12] Mochidzuki, K, Takeuchi, Y. The effects of some inhibitory components on biological activated carbon processes. Water Research 33 (11): pp 2609-2616, 1999. 